\title{
Contributions to the study of porosity in fly ash-based geopolymers. Relationship between degree of reaction, porosity and compressive strength
}

\author{
Y. Luna-Galiano ${ }^{a} \bowtie$, C. Fernández-Pereira ${ }^{a}$, M. Izquierdo ${ }^{b}$ \\ a. University of Seville, School of Engineering, Chemical and Environmental Engineering Department. (Seville, Spain) \\ b. School of Biosciences, University of Nottingham (Sutton Bonington, United Kingdom) \\ \yluna@us.es \\ Received 20 November 2015 \\ Accepted 14 March 2016 \\ Available on line 20 September 2016
}

\begin{abstract}
The main contribution of this paper relates to the development of a systematic study involving a set of parameters which could potentially have an impact on geopolymer properties: curing temperature, type of activating solution, alkali metal in solution, incorporation of slag (Ca source) and type of slag used. The microstructures, degrees of reaction, porosities and compressive strengths of geopolymers have been evaluated. Geopolymers prepared with soluble silicate presented a more compacted and closed structure, a larger amount of gel, lower porosity and greater compressive strength than those prepared with hydroxides. On the other hand, Na-geopolymers were more porous but more resistant than K-geopolymers. Although there is an inverse relation between degree of reaction and porosity, between compressive strength and porosity it is not always inversely proportional and could, in some cases, be masked by changes produced in other influencing parameters.
\end{abstract}

KEYWORDS: Fly ash; Blast furnace slag; Alkali-activated cement; Compressive Strength; Pore size distribution

Citation/Citar como: Luna-Galiano, Y.; Fernández-Pereira, C.; Izquierdo, M. (2016) Contributions to the study of porosity in fly ash-based geopolymers. Relationship between degree of reaction, porosity and compressive strength. Mater. Construcc. 66 [324], e098. http://dx.doi.org/10.3989/mc.2016.10215.

RESUMEN: Contribuciones al estudio de la porosidad de geopolímeros basados en cenizas volantes. Relación entre grado de reacción, porosidad y resistencia a compresión. La principal contribución de este documento es el desarrollo de un estudio sistemático implicando una serie de parámetros que podrían afectar a las propiedades de los geopolímeros: temperatura de curado, solución activadora, metal alcalino de la solución, incorporación de escorias (fuente de calcio) y tipo de escorias. Se han evaluado: microestructura, grado de reacción, porosidad y resistencia a compresión. Los geopolímeros preparados con silicatos presentaron un microestructura más densa y compacta, una mayor cantidad del gel geopolimérico, menor porosidad y mejores propiedades mecánicas que los preparados con hidróxidos. Los geopolímeros preparados con sales de sodio fueron más porosos pero más resistentes que los preparados con sales potasio. Aunque existe una relación inversa entre el grado de reacción y la porosidad, en algunos casos, la relación entre resistencia y porosidad es inexistente ya que puede estar enmascarada por cambios producidos por otros parámetros que afecten a la reacción.

PALABRAS CLAVE: Ceniza volante; Escoria de alto horno; Cemento activado alcalinamente; Resistencia a la compresión; Distribución de tamaño de poro

Copyright: (C) 2016 CSIC. This is an open-access article distributed under the terms of the Creative Commons Attribution License (CC BY) Spain 3.0. 


\section{INTRODUCTION}

Coal-based power generation produces large amounts of fly ash worldwide. An estimated 780 million tonnes of coal ash are produced every year, but less than $50 \%$ of global production is utilised (1). The synthesis of geopolymers may be a successful alternative to re-use coal ash as added-value products resulting in low cost and environmentally friendly materials with cementing properties resembling those of Ordinary Portland Cement (OPC) (2). The term geopolymer was introduced by Davidovits in the early 1970 s to describe inorganic materials obtained from the chemical reaction of some alumino-silicate precursors with alkali silicates, yielding polymeric Si-O-Al bonds (3). The network consists of $\mathrm{SiO}_{4}$ and $\mathrm{AlO}_{4}$ tetrahedron linked alternately by sharing the oxygens. Studies conducted in recent years have resulted in the development of geopolymers based on natural materials (mainly kaolinite and metakaolin) or industrial wastes, with particular emphasis on pulverised coal combustion fly ash (4-7). The synthesis of geopolymers using coal ash may involve environmental benefits including a reduction in the consumption of natural resources and a decrease in net production of $\mathrm{CO}_{2}$. It is estimated that the geopolymer cement synthesis emits 5-6 times less $\mathrm{CO}_{2}$ than Portland cement (8).

Geopolymerization has become a promising technology that offers attractive possibilities for commercial applications, i.e. fast hardening, high and early compressive strength, optimal acid resistance and long term durability (9-11). However, the performance of the final product in these applications is heavily reliant on the physical properties of geopolymers and more specifically, the microstructure and porosity. Previous studies carried out by other authors suggest that optimal dosages, manufacturing and curing conditions are the key in obtaining geopolymer bodies with low porosity and long-term stability $(7,12)$. Porosity and pore size distribution are the main properties to analyse in order to study corrosion in geopolymeric concrete since they determine the permeability of the geopolymeric matrix (13).

Mercury Intrusion Porosimetry (MIP) is extensively used across a number of applications for which porosity is a critical parameter, including cementitious materials derived from Portland cement. However, the literature on concrete and mortars suggests that MIP may not always be highly reliable. Some researchers found that the pores measured by MIP applied on cementitious materials can be smaller than the pores observed with SEM (14-16). Despite these limitations, the MIP technique is generally considered an appropriate method of porosity analysis and a useful tool to examine optimal dosages and curing conditions for comparative purposes.
A great deal of porosimetry data related to fly ash-based geopolymers can be found in the literature, however, many studies often present inconsistent findings or are contradictory. As a previous step to the experimental research described in this paper, a state of the art study on the subject was conducted in order to find the most relevant factors affecting ash geopolymer porosity.

Some research clearly evidences that the water to solids ratio $(\mathrm{w} / \mathrm{s})$ of the mixtures has an important effect on the pore size distribution of the cured geopolymers. Thus, for the same conditions, as the w/s increases, porosity also increases $(14,17)$. Water is consumed only marginally during the alkali activation process in ash geopolymers (like in metakaolin geopolymers). For this reason, the volume fraction of the liquid activator governs the final open porosity of the geopolymers (18). This explains why the total porosity of metakaolin based geopolymers, which require large quantities of activator to obtain a workable paste, is often higher than that of fly ash based geopolymers (19).

Curing temperature and curing time also play an important role in the definition of geopolymer porosity. In general, a systematic increase in the total volume of pores is observed when the curing temperature increases. However, the results are not so conclusive with regard to pore size variation. Inconsistent results have also been found in relation to the variation of porosity and pore size distribution during the curing time. Thus, in general, porosity declines over time (20). Additionally, a refinement of pores has been described in some cases, whereas in other mixtures the pore size distributions and the total porosity scarcely changed over time $(19,21)$.

Another factor with a great influence on ash geopolymer porosity is the presence of blast furnace slag (BFS) in the geopolymer composition, which is associated with the role of calcium in the geopolymeric reaction. Thus, it has been verified that as the amount of BFS in the mixture increases, replacing fly ash, geopolymer porosity reduces lineally and the pore size distribution is shifted to a micro-porosity $(22,23)$

The influence of the nature of the activating solution on geopolymer porosity has also been studied, comparing results obtained with and without soluble silicate. Moreover, it has been proved that an increase of $\mathrm{Na}_{2} \mathrm{O}$ in systems activated with sodium silicate and $\mathrm{NaOH}$ produces dense matrices with small pores, probably due to the great development of the geopolymeric reaction (24). The influence of the Si/Al ratio has also been studied, although not always showing the same results $(25,26)$.

The effect and role of alkali metal (Na or K) used for the synthesis of geopolymers have been a matter of discussion for a long time (27-29). One of the more repeatedly studied properties is the strength 
TABLE 1. Chemical composition of raw materials (w/w\%)

\begin{tabular}{|c|c|c|c|c|c|c|c|c|c|c|c|}
\hline & \multirow{2}{*}{$\begin{array}{c}\text { Moisture } \\
105^{\circ} \mathrm{C}\end{array}$} & \multirow{2}{*}{$\begin{array}{c}\text { LOI } \\
7^{750}{ }^{\circ} \mathrm{C}\end{array}$} & \multicolumn{7}{|c|}{ Oxides } & \multirow{2}{*}{$\begin{array}{l}\text { Degree of } \\
\text { reaction (\%) }\end{array}$} & \multirow{2}{*}{$\begin{array}{c}\text { Vitreous } \\
\text { phase (\%) }\end{array}$} \\
\hline & & & $\mathrm{Fe}_{2} \mathrm{O}_{3}$ & $\mathrm{CaO}$ & MgO & $\mathrm{SiO}_{2}$ & $\mathrm{Al}_{2} \mathrm{O}_{3}$ & $\mathrm{Na}_{2} \mathrm{O}$ & $\mathbf{K}_{2} \mathbf{O}$ & & \\
\hline FA & 0.05 & 3.32 & 5.86 & 3.94 & 1.84 & 63.9 & 21.5 & 0.68 & 1.67 & 17.7 & 72.3 \\
\hline BFS & 0.24 & 0.31 & 0.49 & 45.8 & 6.52 & 32.1 & 15.0 & 0.32 & 0.26 & 96.1 & 57.1 \\
\hline MS & 0.45 & 1.90 & 1.53 & 43.8 & 9.52 & 31.6 & 4.41 & 0.60 & 0.07 & 85.6 & 50.1 \\
\hline
\end{tabular}

achieved by the geopolymer when $\mathrm{NaOH}, \mathrm{KOH}$, $\mathrm{Na}_{2} \mathrm{SiO}_{3}, \mathrm{~K}_{2} \mathrm{SiO}_{3}$ or mixtures $\mathrm{M}_{2} \mathrm{SiO}_{3}+\mathrm{MOH}(\mathrm{M}$ : $\mathrm{Na}$ or $\mathrm{K}$ ) are used as the activating solution, presenting contradictory results in many cases (30-32). In relation to this, the use of sodium or potassium silicates as alkaline activators is of special interest due to their different market prices. Other authors have concluded that the use of potassium silicate instead of sodium silicate improved the mechanical properties of the final products (33), which could compensate for its higher cost.

The main contribution of this paper relates to the development of a systematic study, involving a set of parameters which could potentially have an impact on geopolymer porosity, i.e. the curing temperature, type of activating solution, incorporation of slag ( $\mathrm{Ca}$ source) to the mixtures and type of slag. Additionally, the compressive strength and the degree of reaction of the geopolymer specimens have been measured and the possible correlations among compressive strength, porosity and degree of reaction have also been considered. Furthermore, this research has been completed with a microstructural study of the ash geopolymers manufactured.

\section{MATERIALS AND METHODS}

\subsection{Materials}

A low calcium fly ash (class F ASTM) from one of the largest coal power stations in Southern Spain (Los Barrios, Cádiz (550 MW)) was used as the main aluminosilicate source. Ground granulated blast furnace slag (BFS) and metallurgical slag (MS) were used as calcium and silicon additions and were provided by Holcim S.A. and Acerinox S.A., respectively. The chemical composition of these constituents (Table 1) was determined after chemical attack and dissolution at $750{ }^{\circ} \mathrm{C}$ (ASTM D-3682-78) (34) using atomic absorption spectroscopy. The vitreous phase of FA, BFS and MS (Table 1) has been calculated as described in a study by Arjuan (35). The raw materials were also subjected to a degree of reaction test (Table 1), a method described by Fernández-Jiménez $(36,37)$. This parameter was calculated as the percentage of soluble material after a selective hydrochloric acid dissolution attack of the samples lasting 3 hours. The degree of reaction gives some idea of
TABLE 2. Particle size distribution of raw materials

\begin{tabular}{lccc}
\hline & \multicolumn{3}{c}{$\begin{array}{c}\text { Differential particle size } \\
\text { distribution }(\mathbf{w t} \%)\end{array}$} \\
\cline { 2 - 4 } $\begin{array}{l}\text { Average } \\
\text { diameter }(\boldsymbol{\mu m})\end{array}$ & FA & BFS & MS \\
\hline$>400$ & 1.21 & - & 48.5 \\
225 & 5.53 & - & 30.3 \\
112 & 9.82 & 1.44 & 15.6 \\
59.5 & 5.42 & 6.86 & 3.52 \\
22.5 & 78.0 & 91.7 & 2.11 \\
\hline
\end{tabular}

the amount of fly ash converted in geopolymeric cement. This parameter was measured with a $0.5 \%$ coefficient of variation. The particle size distribution of raw materials was determined by sieving and the results are shown in Table 2. The $\mathrm{D}_{50}$ of FA, BFS and MS have been calculated and are 42.8 $\mu \mathrm{m}, 34.6 \mu \mathrm{m}$ and $387 \mu \mathrm{m}$, respectively.

Different activating solutions were tested. Two of them were based exclusively on hydroxides: (i) $8 \mathrm{M}$ $\mathrm{KOH}$ and (ii) $8 \mathrm{M} \mathrm{NaOH}$, using sodium hydroxide and potassium hydroxide pellets with $99 \%$ and $85 \%$ (w/w\%) purity, respectively, and distilled water. The other two activating solutions consisted of a combination of hydroxide and soluble silicate i.e. (iii) a mixture of K-silicate (KSil) solution $\left(\mathrm{SiO}_{2} 23 \mathrm{w} / \mathrm{w} \%\right.$ and $\mathrm{K}_{2} \mathrm{O} 14.9 \mathrm{w} / \mathrm{w}^{\%} \%$ ) (Industrias Químicas del Ebro) and enough $\mathrm{KOH}$ to increase the $\mathrm{K}_{2} \mathrm{O} / \mathrm{SiO}_{2}$ molar ratio up to 1.45 ( $\mathrm{pH}$ of solution is 13.5 ); and (iv) a mixture of $\mathrm{Na}$-silicate $(\mathrm{NaSil})$ solution $\left(\mathrm{SiO}_{2}\right.$ $27 \mathrm{w} / \mathrm{w} \%$ and $\mathrm{Na}_{2} \mathrm{O} 8 \mathrm{w} / \mathrm{w} \%$ ) (Merck) and $\mathrm{NaOH}$ in order to increase the $\mathrm{Na}_{2} \mathrm{O} / \mathrm{SiO}_{2}$ molar ratio up to $0.98(\mathrm{pH}$ of solution is 13.5$)$.

\subsection{Geopolymer preparation}

The geopolymer mixtures were prepared in a common laboratory mixer at $500 \mathrm{rpm}$. Firstly, solid materials were blended until a homogeneous mix was obtained. Finally, an activating solution was added to the solid mixture until a workable and thixotropic paste was achieved. The mixing time was around 4 minutes. The reader can refer to Luna et al. (38) for further details. Relative proportions of each component in the geopolymers are detailed in Table 3. Cylindrical plastic moulds $(30 \mathrm{~mm}$ diameter and $41 \mathrm{~mm}$ height) were filled with the paste obtained. The pastes were vibrated for 5 minutes 
TABLE 3. Relative proportion (by mass) of each component for each series of geopolymers

\begin{tabular}{|c|c|c|c|c|c|c|c|c|c|}
\hline & FA & BFS & MS & NaSil & $\mathrm{NaOH}$ & KSil & KOH & $\begin{array}{c}\mathrm{NaOH} \\
\text { solution } 8 \mathrm{M}\end{array}$ & $\begin{array}{c}\mathrm{KOH} \\
\text { solution } 8 \mathrm{M}\end{array}$ \\
\hline $\mathrm{NaOH} 8 \mathrm{M}$ & 1.4 & - & - & - & - & - & - & 0.56 & - \\
\hline $\mathrm{NaSil} \mathrm{NaOH}$ & 1.4 & - & - & 0.8 & 0.16 & - & - & - & - \\
\hline NaSil NaOH BFS & 1.4 & 0.3 & - & 0.8 & 0.16 & - & - & - & - \\
\hline NaSil NaOH MS & 1.4 & - & 0.3 & 0.8 & 0.16 & - & - & - & - \\
\hline $\mathrm{KOH} 8 \mathrm{M}$ & 1.4 & - & - & - & & - & - & - & 0.56 \\
\hline KSil KOH & 1.4 & - & - & - & & 0.8 & 0.42 & - & - \\
\hline KSil KOH BFS & 1.4 & 0.3 & - & - & & 0.8 & 0.42 & - & - \\
\hline KSil KOH MS & 1.4 & - & 0.3 & - & & 0.8 & 0.42 & - & - \\
\hline
\end{tabular}

to release entrapped gas bubbles. The samples were cured in two different conditions: half of the specimens were maintained at room temperature and the others were cured in an oven at $60^{\circ} \mathrm{C}$.

\subsection{Physical and mechanical properties of geopolymers}

Compressive strength tests were carried out after 7, 28 and 60 days of curing in accordance with ASTM C39 (39) using two or three specimens of each sample and averaging the experimental values obtained. The coefficients of variation were $<1 \%$. A Suzpecar, mod. MEM-102/50 t, compressive strength testing frame was used. The microstructure of the geopolymers was studied after 7 days of curing using a scanning electron microscope (SEMFEG) Hitachi S-4800 coupled with an EDX detector. The degree of reaction was also determined after 7, 28 and 60 days of curing. The porosity study was carried out after 7 days of curing using an Autopore IV 9500 mercury intrusion porosimeter after drying the specimens at $60{ }^{\circ} \mathrm{C}$ for 48 hours. As the contact angle employed was $130^{\circ}$ (as is usually adopted for evaluating the pore structure by mercury penetration $(40,41))$, the measured average pore sizes range theoretically from $0.003-905 \mu \mathrm{m}$.

\section{RESULTS}

\subsection{Geopolymer microstructure}

Fly ash based geopolymers can be described as a multi-component system that consists of (i) a relatively dense packing of unreactive particles from starting materials i.e. fly ash and slag, (ii) an undifferentiated and homogeneous mass surrounding and cementing particles i.e. the geopolymer binder, and (iii) both intergranular and intragranular pore networks. Spherical-shaped fly ash particles are present in all geopolymer samples cured at room temperature, which suggests only partial ash dissolution to produce the geopolymer matrix. The absence of full dissolution is consistent with low temperature activation and has been reported by several authors (10). The relative proportion of the geopolymer matrix over the other two components (ash/slag and porosity) gives an indication of the reactivity of the system and the overall degree of geopolymerization. Thus, geopolymer development seems to be limited when hydroxides are used alone as activators, regardless of whether they are $\mathrm{NaOH}$ (Figure 1b) or $\mathrm{KOH}$ (Figure 1c). In general, no significant differences are observed between the appearance of the two geopolymers from that of the parent fly ash (Figure 1a), exhibiting limited activation and low reactivity. In general, poor development of geopolymer binder is observed, with a highly porous microstructure consisting of fly ash cenospheres coated in a layer of a fine material composed of $\mathrm{Si}$ and $\mathrm{Al}$ compounds.

The use of silicate as activating solution (with alkali hydroxide to increase the $\mathrm{Na} / \mathrm{Si}$ ratio) dramatically changes the microstructure (Figure 1d and 1e). A substantial degree of geopolymer development is observed, with a large amount of unreacted fly ash particles embedded in a homogeneous amorphous matrix, whilst the majority of small cenospheres are presumably dissolved and disappeared almost completely. The amorphous phase is known as alkaline aluminium silicate hydrate gel (N-A-S-H gel, so-called since it is formed during the activation with $\mathrm{Na}$-silicate), a rich $\mathrm{Si}$ and $\mathrm{Al}$ material produced during the reaction between fly ash and the activating solution. Figure 1e shows a cenosphere enclosed in the matrix and surrounded by a layer of a different material in which mullite is detected. Small layers of sodium compounds and $\mathrm{Si}$ and $\mathrm{Ca}$ rich areas are also observed. This system appears to be much less porous than the hydroxide geopolymers shown in Figure $1 \mathrm{~b}$ and $1 \mathrm{c}$ as the newly formed homogeneous mass of geopolymer binder filled interstitial porosity. However, persistent isolated porosity is present (Figure 1d), which is consistent with other studies $(6,12)$. Cenospheres account for most isolated vesicles, but randomly distributed gas cavities are also present. 

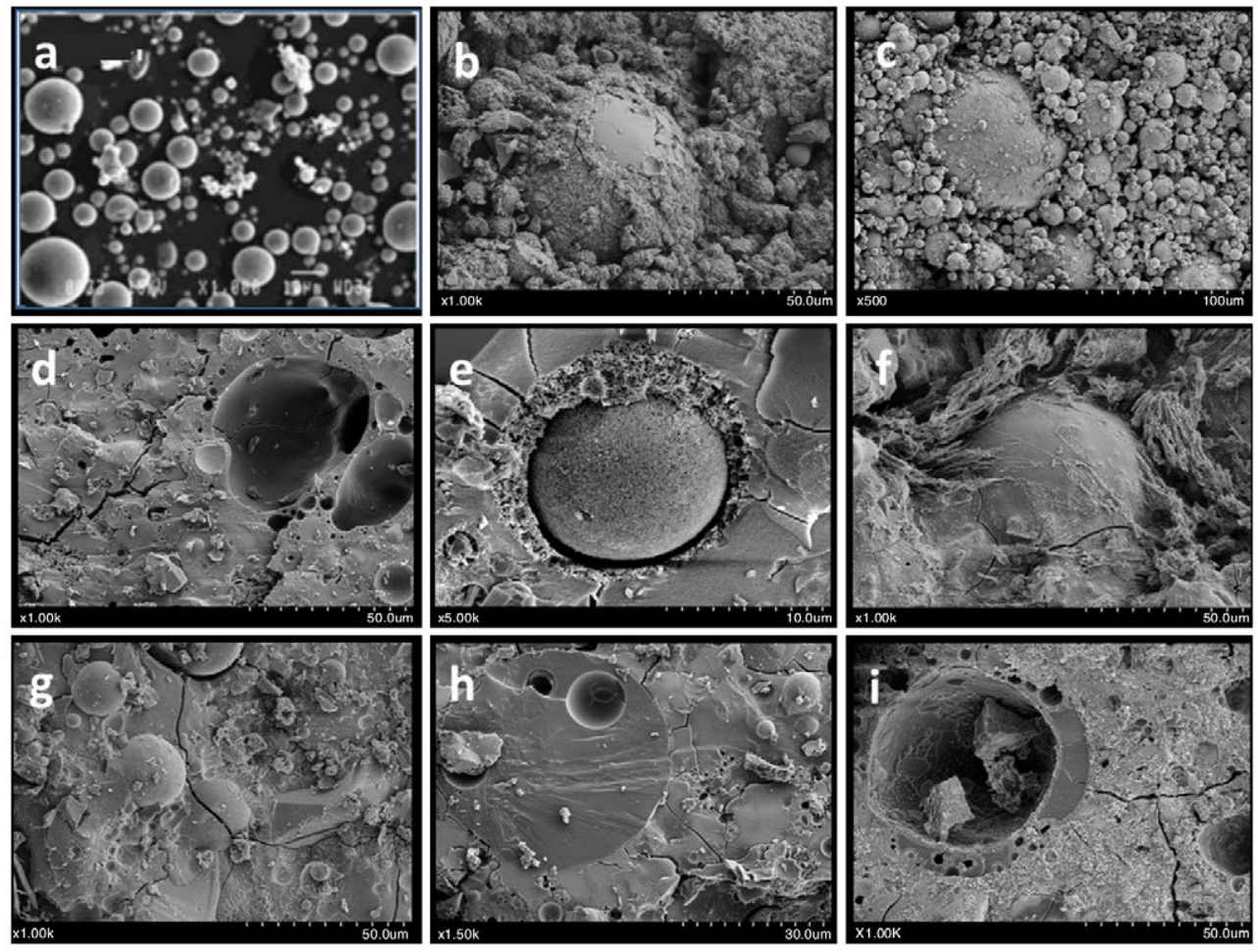

Figure 1. SEM Images of a) Fly ash, b) NaOH-geopolymer, c) KOH-geopolymer, d) and e) NaSil NaOH-geopolymers, f) NaSil NaOH MS-geopolymer, g) and h) NaSil NaOH BFS-geopolymers, i) KSil KOH BFS-geopolymer.

As can be seen, the addition of slag to the mixture does not significantly change the microstructure (Figure 1f, 1g and 1h). A well-developed geopolymeric matrix is observed, although this seems to be less homogeneous and uniform than that observed when no slag is used (Figure 1d and 1e). The presence of laminar structures rich in $\mathrm{Ca}, \mathrm{Mg}$ and $\mathrm{Si}$ is distinctive of MS-containing geopolymers. The gel is coated in a crystalline layer formed by $\mathrm{Si}$ and $\mathrm{O}$ (silica), which is prevailing in MS-geopolymers, and by particles containing $\mathrm{Ca}$ and $\mathrm{Si}$ in BFS-geopolymers.

In Figure 1h, the geopolymeric gel can be clearly observed. Hollow cenospheres with geopolymeric gel filling intragranular pores provide evidence of partial dissolution taking place during the alkaline attack. This enables the entry and growth of the newly formed geopolymer binder within the ash particle. Further evidence of the extent of activation is the internal rim of the cenosphere (Figure 1i), which is an attacked zone of amorphous nature, rich in $\mathrm{Al}, \mathrm{K}$ and $\mathrm{Si}$ (gel K-A-S-H formed during the activation of the material with $\mathrm{K}$-silicate).

\subsection{Degree of reaction}

The determination of the degree of reaction was carried out in all geopolymer samples. Figures $2 \mathrm{a}$ and $2 \mathrm{~b}$ show the values obtained after 7,28 and 60 days of curing at room temperature $\left(25^{\circ} \mathrm{C}\right)$ and $60{ }^{\circ} \mathrm{C}$, respectively.
As can be seen, K-silicate geopolymers present higher degrees of reaction than Na-silicate geopolymers. The two silicate solutions $(\mathrm{K}$ or $\mathrm{Na}$ ) present similar $\mathrm{pH}$ values, but the concentration of alkali is different in the solutions: $\mathrm{SiO}_{2} / \mathrm{K}_{2} \mathrm{O}$ molar ratio of 0.689 in K-silicate (KSil) and $\mathrm{SiO}_{2} / \mathrm{Na}_{2} \mathrm{O}$ molar ratio of 1,02 in Na-silicate (NaSil). As remarked by Duxson (27), solutions with low concentrations of silicon improve the rate of mass transport and promote dissolution in the geopolymerization reaction, so the percentage of unreacted material is low. Therefore, the low $\mathrm{Si} / \mathrm{K}$ ratio could explain the large amount of geopolymeric gel shown by the $\mathrm{K}$-silicate systems. Systems with hydroxide show the same behaviour: $\mathrm{KOH}$ geopolymers always display a higher degree of reaction values than $\mathrm{NaOH}$ geopolymers. Sindhunata (9) mentioned that systems activated with $\mathrm{K}$ were more efficient in the dissolution stage of the aluminosilicate than systems activated with $\mathrm{Na}$, but did not conclude if $\mathrm{K}$-systems were more reactive than Na-systems. In the recent work, it has been confirmed that the attack with $\mathrm{HCl}$ dissolves more amount of gel in the K-geopolymers than in Na-geopolymers.

An increase in reactivity is also clearly appreciable in geopolymers containing slag. Na-silicate fly ash based geopolymer cured at room temperature for 7 days shows a degree of reaction of $46 \%$, which indicates that $54 \%$ is unreacted fly ash. The addition of BFS to the mixture produces an increase 


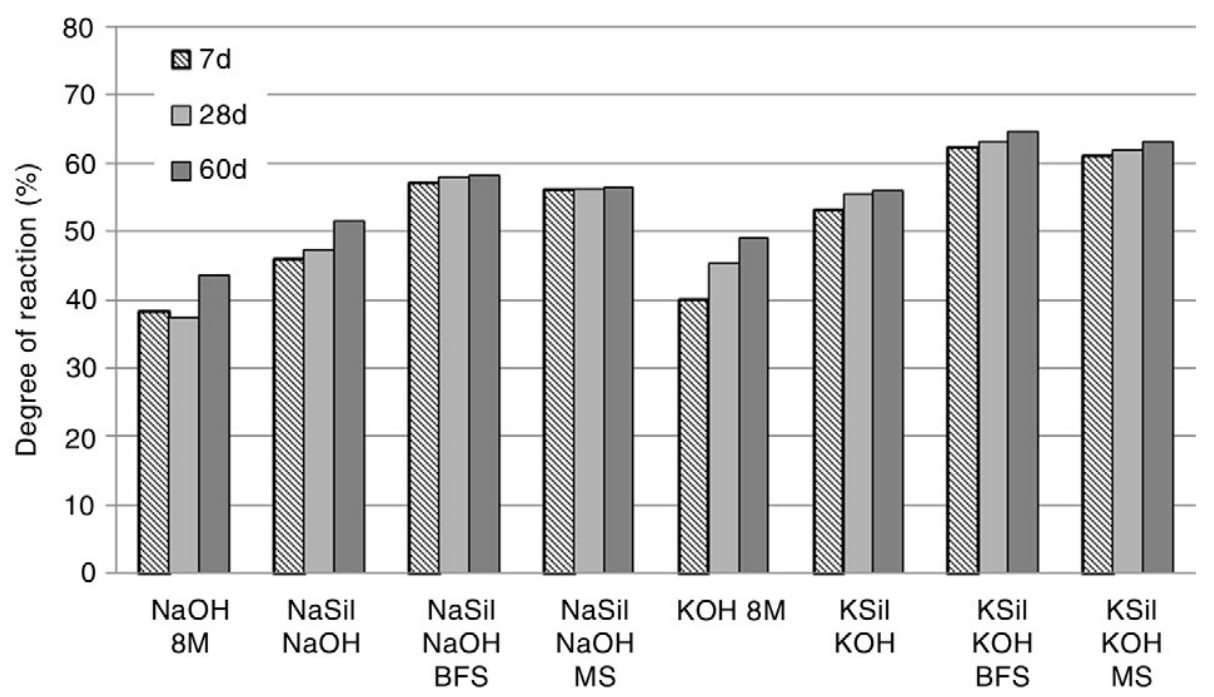

Figure 2a. Degree of reaction (\%) of geopolymers cured at room temperature.

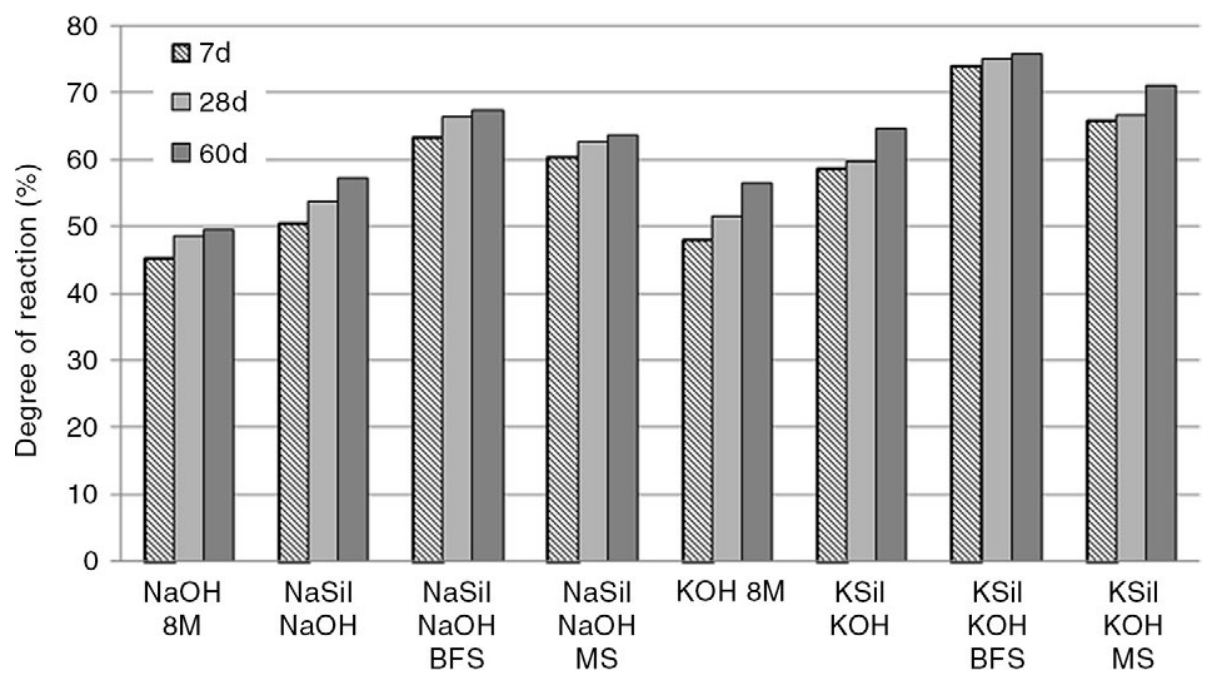

Figure 2b. Degree of reaction (\%) of geopolymers cured at $60{ }^{\circ} \mathrm{C}$.

in degree of reaction from $46 \%$ to $57 \%$. This increment could be due to the different reactivity of raw materials when they are subjected to the $\mathrm{HCl}$ attack (Table 1), slags reactivity (BFS 96.1\% and MS $85.6 \%)$ is higher than fly ash reactivity $(17.1 \%)$. In addition, particle size distribution could also affect this, mainly in BFS-geopolymers, since BFS contains the finest particle size (Table 2). The use of the metallurgical slag (MS) also produces an increase in the geopolymeric gel, but this increment is lower than that observed in the BFS-geopolymers, possibly due to the lowest reactivity and the highest pore size distribution of MS. However, the degree of reaction value of $46 \%$ in the fly ash based geopolymer cannot be explained only by these two parameters (reactivity or pore size distribution). The vitreous phase percentage, another variable that affects the activation process, should also be taken into account. An acceleration of the geopolymerization reaction and an increase in the degree of reaction are observed in geopolymers based on a high percentage of vitreous phase raw materials (42). As can be seen in Table 1, the fly ash vitreous phase $(72.3 \%)$ is higher than the corresponding value of BFS (57.1\%) and MS (50.1\%). Examining the results of Figure $2 a$ and $2 b$, it seems that the vitreous phase is the parameter that controls the degree of reaction in the activation of fly ashes, but the reactivity and particle size distribution must also be taken into account in reactions with slags. In any case, the presence of slag results in a high interconnected gel-like network with precipitates of calcium silicate hydrate gel, which can embrace a small percentage of aluminium in its structure, forming calcium aluminium silicate hydrate gel (43), which acts as nucleation sites $(44,45)$. 
Regarding the curing temperature, in all the cases the highest degrees of reaction are obtained when geopolymers are cured at $60^{\circ} \mathrm{C}$. As it is well known, thermal activation could accelerate geopolimerization reactions (46) and could cause an increase in the extent of reaction. The degree of reaction also changes over the time studied (7-60 days). The values increase up to $9 \%$, especially in certain Na-geopolymers, but this increase is not as important as the increase which occurred in the first stages. However, the degree of reaction should continuously grow until the total available material is consumed by the activating solution.

\subsection{Porosity}

Porosity of geopolymers measured as total mercury intrusion volume ranged from $0.0766 \mathrm{~mL} \cdot \mathrm{g}^{-1}$ to $0.202 \mathrm{~mL} \cdot \mathrm{g}^{-1}$. Average pore diameters varied over the range 0.03-0.99 $\mu \mathrm{m}$ (Table 4).

As anticipated with SEM observations in Figure $1 \mathrm{~b}$ and c, geopolymers activated exclusively with hydroxides present a microstructure of a non-reactive system, with fly ash particles loosely connected, so the empty space between particles is higher than in reactive systems. Therefore, the pore volume and the pore diameter in hydroxide-activated geopolymers are greater than in silicate-activated geopolymers.

For a given composition and curing temperature, geopolymers produced with Na-activators are more porous and present higher average pore diameters than those with K-activators. Lloyd et al. (14) found that geopolymers obtained using $\mathrm{K}$ or $\mathrm{Na}+\mathrm{K}$ activators were more porous than those manufactured using Na-activators, although the authors did not find a clear explanation for this. Conversely, Kriven and Bell (47) studied metakaolin based geopolymers activated with sodium silicate containing $\mathrm{NaOH}$, $\mathrm{KOH}$ or mixtures of both in different proportions and found that the mean pore size decreases almost monotonically as sodium was progressively replaced by potassium in the geopolymer mixtures. In the current work, K-silicate geopolymers show a higher degree of reaction than Na-silicate geopolymers
(Figure $2 \mathrm{a}$ or $2 \mathrm{~b}$ ), so it is possible that systems with a high extent of reaction have a large amount of geopolymeric gel, also present small spaces between unreactive particles and therefore a low porosity.

The addition of BFS is found to exert an influence on porosity. For a given dosage and curing temperature, geopolymers prepared with BFS are less porous than geopolymers without BFS. This is in line with the findings of Provis et al. (22) who found that the use of BFS instead of fly ash in geopolymers leads to a decrease in porosity, possibly due to the different chemistry existing in fly ash and BFS geopolymers. Puligilla and Mondal (48) proposed that the simultaneous formation of the geopolymeric gel and the calcium aluminium silicate hydrate gel (formed in presence of $\mathrm{Ca}$ ) may help to fill the gaps between the different hydrated phases and the unreacted particles, resulting in a more dense and homogeneous matrix. However, there are no thorough conclusions about the contribution of the different gels, so other parameters should probably be taken into account. This general trend is not observed for MS geopolymers, since the porosity values change very marginally, because MS slag has a higher average particle size (Table 2) and a lower reactivity than BFS slag (Table 1).

Geopolymer porosity is largely affected by the thermal activation during curing. In general, geopolymers cured at $60{ }^{\circ} \mathrm{C}$ show lower average pore sizes and higher total pore volumes than those cured at room temperature. Other authors reported a similar effect $(19,49,50)$, concluding that most of the porosity of geopolymers cured at a high temperature was associated with small pores (less than $0.01 \mu \mathrm{m}$ ), while geopolymers cured at room temperature were dominated by pores in the range 0.1-1 $\mu \mathrm{m}$. Two effects must be taken into account in order to explain this behaviour. The first is the effect of temperature on the degree of reaction. Samples cured at room temperature show the lowest degree of reaction (Figure $2 \mathrm{a}$ and $2 \mathrm{~b}$ ), which could be related to the high porosity of the geopolymers cured at room temperature. The second has to do with the syneresis phenomenon, which

TABLE 4. Porosity (as total intrusion volume) and average pore diameter of geopolymers

\begin{tabular}{|c|c|c|c|c|c|}
\hline & $\begin{array}{l}\text { Total intrusion } \\
\text { volume }\left(\mathrm{mL} \cdot \mathrm{g}^{-1}\right)\end{array}$ & $\begin{array}{c}\text { Average pore } \\
\text { diameter }(\mu \mathrm{m})\end{array}$ & & $\begin{array}{l}\text { Total intrusion } \\
\text { volume }\left(\mathrm{mL} \cdot \mathrm{g}^{-1}\right)\end{array}$ & $\begin{array}{c}\text { Average pore } \\
\text { diameter }(\mu \mathrm{m})\end{array}$ \\
\hline $\mathrm{NaOH} 8 \mathrm{M}$ AMB & 0.165 & 0.246 & KOH 8M AMB & 0.135 & 0.118 \\
\hline $\mathrm{NaOH} 8 \mathrm{M} 60^{\circ} \mathrm{C}$ & 0.185 & 0.999 & $\mathrm{KOH} 8 \mathrm{M} 60^{\circ} \mathrm{C}$ & 0.144 & 0.296 \\
\hline NaSil NaOH AMB & 0.095 & 0.077 & KSil KOH AMB & 0.090 & 0.028 \\
\hline $\mathrm{NaSil} \mathrm{NaOH} 60^{\circ} \mathrm{C}$ & 0.099 & 0.056 & $\mathrm{KSil} \mathrm{KOH} 60^{\circ} \mathrm{C}$ & 0.093 & 0.089 \\
\hline NaSil NaOH BFS AMB & 0.077 & 0.053 & KSil KOH BFS AMB & 0.059 & 0.059 \\
\hline $\mathrm{NaSil} \mathrm{NaOH}$ BFS $60^{\circ} \mathrm{C}$ & 0.094 & 0.042 & $\mathrm{KSil} \mathrm{KOH} \mathrm{BFS} 60^{\circ} \mathrm{C}$ & 0.074 & 0.061 \\
\hline NaSil NaOH MS AMB & 0.131 & 0.066 & KSil KOH MS AMB & 0.107 & 0.066 \\
\hline $\mathrm{NaSil} \mathrm{NaOH}$ MS $60^{\circ} \mathrm{C}$ & 0.202 & 0.047 & $\mathrm{KSil} \mathrm{KOH} \mathrm{MS} 60^{\circ} \mathrm{C}$ & 0.171 & 0.041 \\
\hline
\end{tabular}


provokes the expulsion of trapped water during contraction of the gel and subsequent pore generation.

To improve our understanding of how temperature and the activating solution affect the porosity, a pore size distribution (PSD) study (intrusion Logdifferential volume $\left(\mathrm{mL} \cdot \mathrm{g}^{-1}\right)$ versus pore diameter $(\mu \mathrm{m}))$ was carried out (Figures 3 ).

When cement pastes are studied using the MIP technique, two different peaks corresponding to the gel pores and capillary pores appear in the pore size distribution. The small pores are formed during the calcium silicate hydrate formation and the pore size diameter ranges from 0.0005 to $0.01 \mu \mathrm{m}$. The capillary pores refer to the space left by the water that does not react during the hydration of cement and range from 0.01 to $10 \mu \mathrm{m}(51)$.

Geopolymers prepared with hydroxide ( $\mathrm{Na}$ or $\mathrm{K}$ ) as activator (Figure $3 \mathrm{a}$ ) present the same pore size distribution, with only one peak around $1 \mu \mathrm{m}$ (range of capillary pores). In the SEM images (Figure 1b and 1c) poor development of the geopolymer gel is observed, so these capillary pores are possibly formed by the space between unreacted fly ash particles. Curing at $60{ }^{\circ} \mathrm{C}$ produces the same distribution, with a slight increase in peak width.

Silicate-geopolymers (Figure 3b) show similar pore size distribution to hydroxide-geopolymers (Figure $3 \mathrm{a}$ ), with one peak in a pore size of $0.5-0.7 \mu \mathrm{m}$, less than $1 \mu \mathrm{m}$ (hydroxide-geopolymers). The mercury intrusion volume (area under the curve) is lower too, in accordance with the higher amount of the geopolymeric gel and its subsequent void filling effect as silicates are used instead of hydroxides. The differences between the use of K-silicates and Na-silicate are small. The $\mathrm{K}$-silicate solution only produces a slight shift to the lowest pore sizes, possibly due to the extent of reaction in K-silicate systems, which is slightly higher than in Na-silicate (Figure $2 \mathrm{a}$ or $2 \mathrm{~b}$ ).

The addition of blast furnace slag (Figure 3c) results in a wider pore size distribution, showing a certain bimodality, with a significant peak in the capillary range $(0.1-10 \mu \mathrm{m})$ and an increase in pore volume in the zone of gel pores $(0.005-0.1 \mu \mathrm{m})$, which is in accordance with the higher degree of reactions of mixtures with BFS.

In general, Table 4 shows that the effect of the alkali element is more clearly appreciable when slag is added to the mixture. In order to understand the effect of alkali, the cumulative pore area versus the pore size diameter of $\mathrm{K}$-silicate and Na-silicate geopolymers with BFS for both curing conditions are represented (Figure $4 \mathrm{a}$ and $4 \mathrm{~b}$ ).

Figure $4 \mathrm{a}$ represents the cumulative pore area of geopolymers containing BFS with both silicates and both curing conditions. At room temperature, curves for both alkalis present a plateau in a similar pore size $(0.015-0.004 \mu \mathrm{m})$ followed by an increase in area up to $0.005 \mu \mathrm{m}$. Increasing the temperature, an elevated increment of pore area is observed in pores less than $0.01 \mu \mathrm{m}$. The only difference between the use of $\mathrm{Na}$ and $\mathrm{K}$ is that the area under the curve is greater in Na-silicate than in K-silicate geopolymer.

Substantial change was observed in total pore area with variation in curing temperatures, increasing the total area with the thermal activation at $60{ }^{\circ} \mathrm{C}$ combined with a general shift to the micropore zone (less than $0.01 \mu \mathrm{m}$ ).

Figure $4 \mathrm{~b}$ shows the cumulative pore area of $\mathrm{K}$-silicate geopolymers with or without slags. The three curves present a plateau. This plateau is shifted to the smaller pores in BFS-geopolymers and shifted to the bigger pores in MS-geopolymers. Geopolymers without slag show intermediate behaviour. The use of MS produces geopolymers

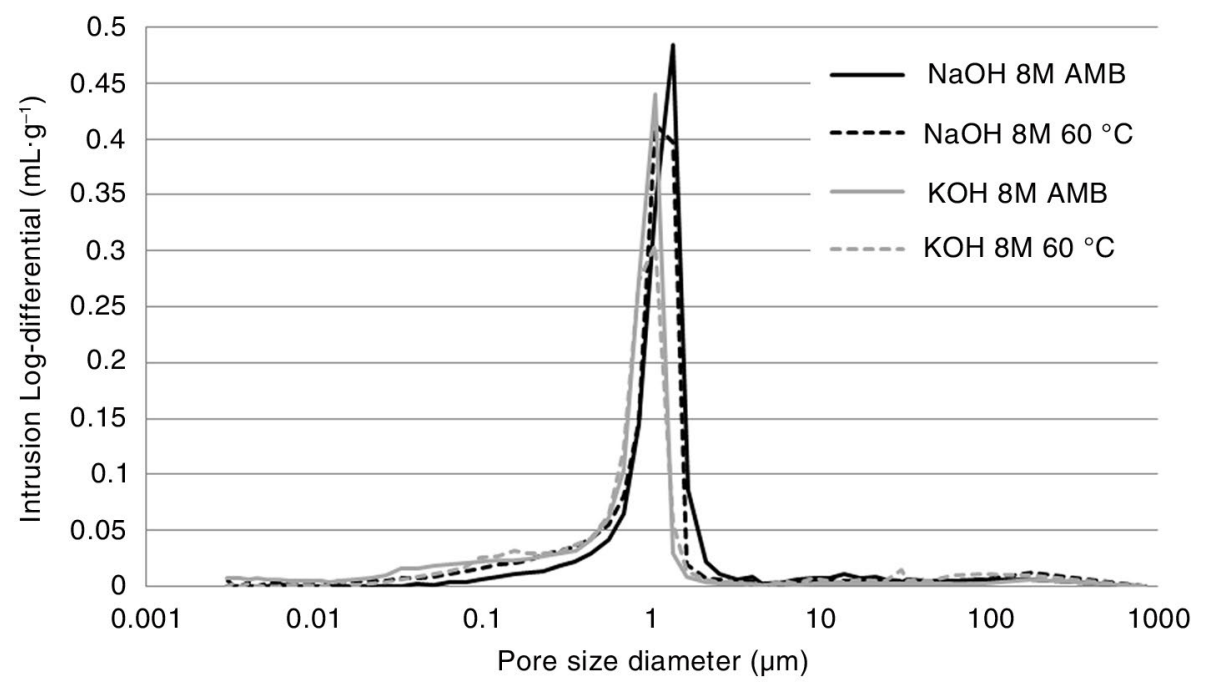

FIgURE 3a. Pore size distribution (Intrusion Log differential $\left(\mathrm{mL} \cdot \mathrm{g}^{-1}\right)$ vs Pore size diameter) of hydroxide-geopolymers. 


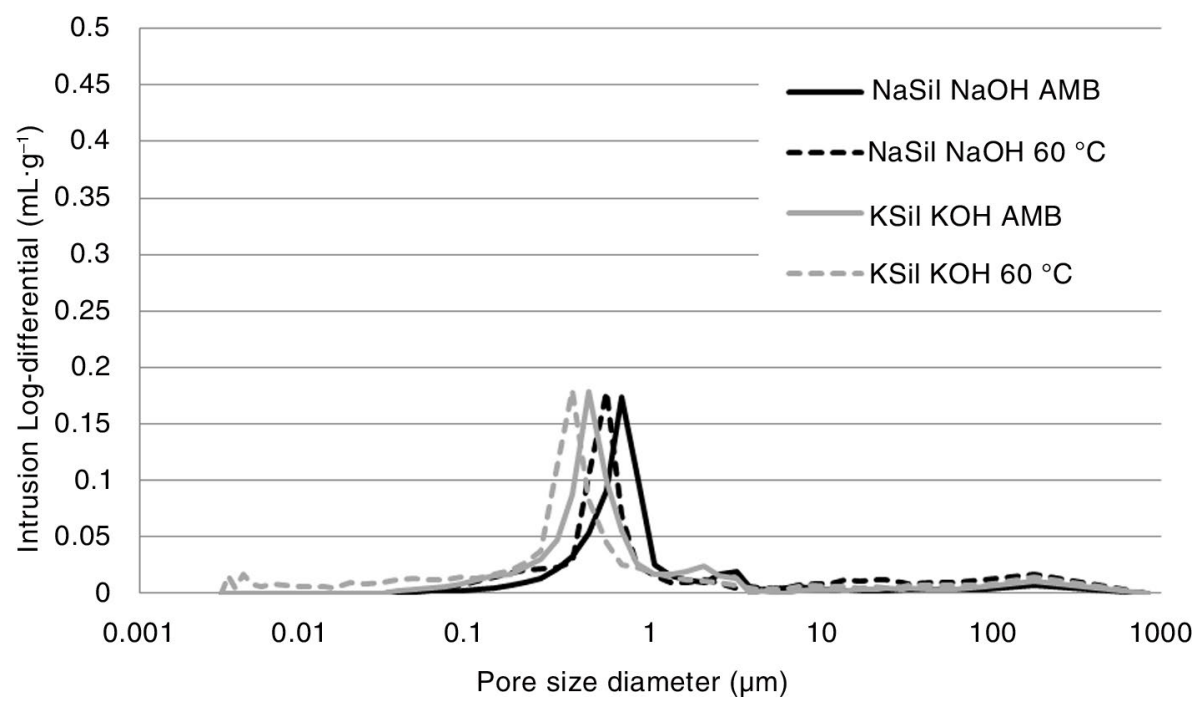

FIGURE 3b. Pore size distribution (Intrusion Log differential $\left(\mathrm{mL} \cdot \mathrm{g}^{-1}\right)$ vs Pore size diameter) of silicate-geopolymers.

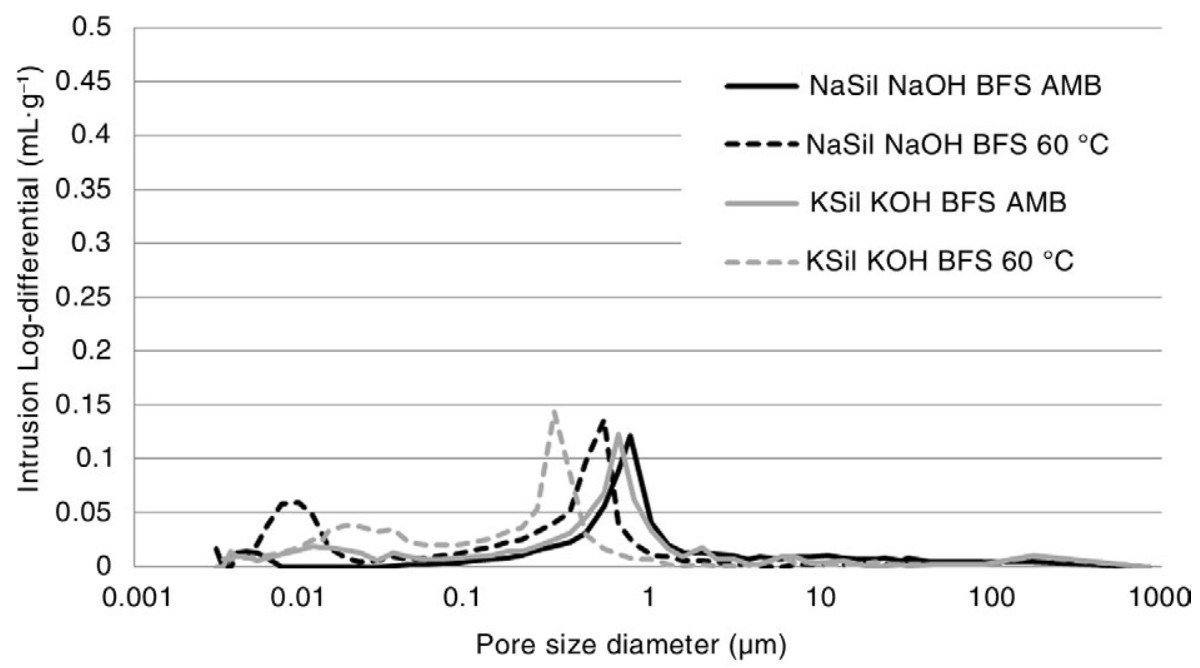

FIGURE 3c. Pore size distribution (Intrusion Log differential $\left(\mathrm{mL} \cdot \mathrm{g}^{-1}\right)$ vs Pore size diameter) of silicate+BFS-geopolymers.

with a greater pore area, possibly due to its coarse pore size distribution.

\subsection{Compressive strength}

Compressive strength results of geopolymers after 7, 28 and 60 days of curing at room temperature and $60{ }^{\circ} \mathrm{C}$ are shown in Figure 5 (Na-geopolymers) and Figure $5 \mathrm{~b}$ (K-geopolymers).

The influence of the type of alkali in geopolymeric activators has been widely discussed in the literature with some controversy since some authors show the positive effect of $\mathrm{Na}$ and others of $\mathrm{K}$. In the current work, the compressive strengths are higher in geopolymers prepared with sodium activators than in those prepared with potassium activators, using either hydroxide or silicate. These results are difficult to explain comparing the values of degree of reaction and the porosity (calculated at 7 days) since K-silicate geopolymers show a higher degree of reaction and lower porosities than $\mathrm{Na}$-silicate geopolymers. On the one hand, $\mathrm{K}$ is more alkaline than $\mathrm{Na}$, so the dissolution rate of aluminosilicates is higher (9) and the degree of reaction and the amount of geopolymeric gel (with lower porosities) are greater. On the other hand, the size of $\mathrm{K}$ is larger than $\mathrm{Na}$, so $\mathrm{K}$ could hinder the evolution process of the prezeolitic gel (52). Moreover, the $\mathrm{K}-\mathrm{A}-\mathrm{S}-\mathrm{H}$ gel is more chemically unstable than the N-A-S-H gel (52), which may explain the lower values of compressive strength of K-geopolymers than Na-geopolymers. In any case, in order to understand the results, the ratio $\mathrm{M}_{2} \mathrm{O} / \mathrm{SiO}_{2}$ (where $\mathrm{M}$ is $\mathrm{Na}$ or $\mathrm{K}$ ) in the activating solution must be taken into account. According to some authors, there is an optimum $\mathrm{M}_{2} \mathrm{O} / \mathrm{SiO}_{2}$ ratio for maximum compressive 


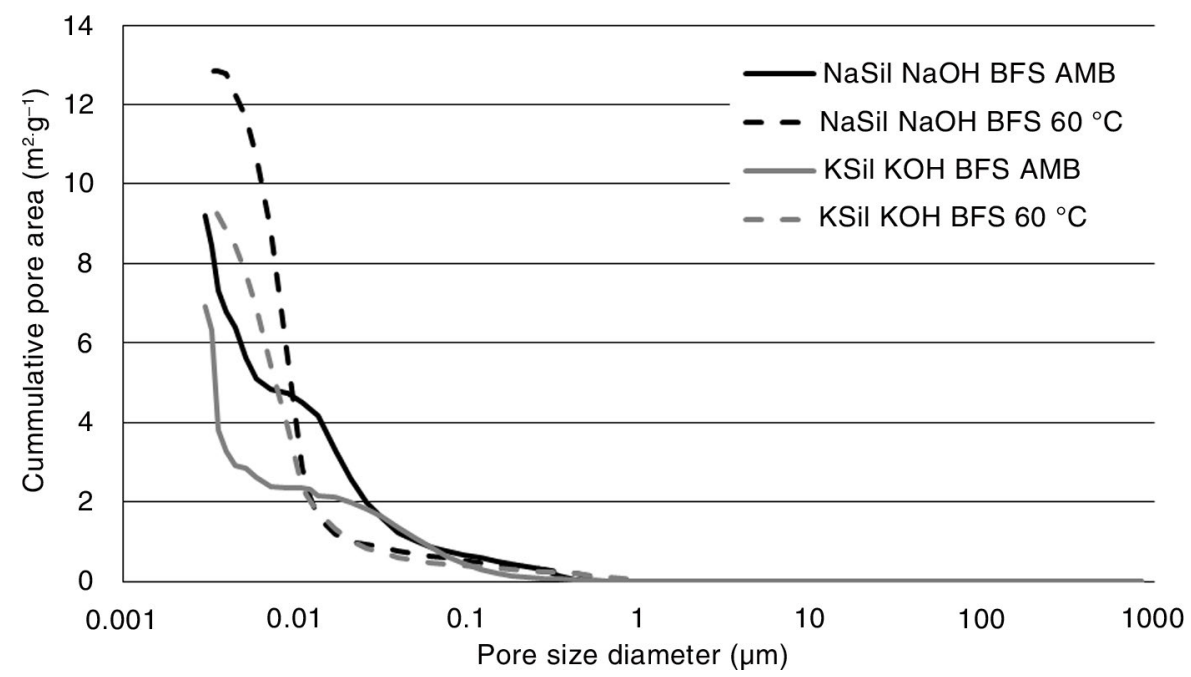

FIgURE 4a. Cumulative pore area $\left(\mathrm{m}^{2} \cdot \mathrm{g}^{-1}\right)$ vs Pore size diameter of BFS-geopolymers (KSilicate and NaSilicate).

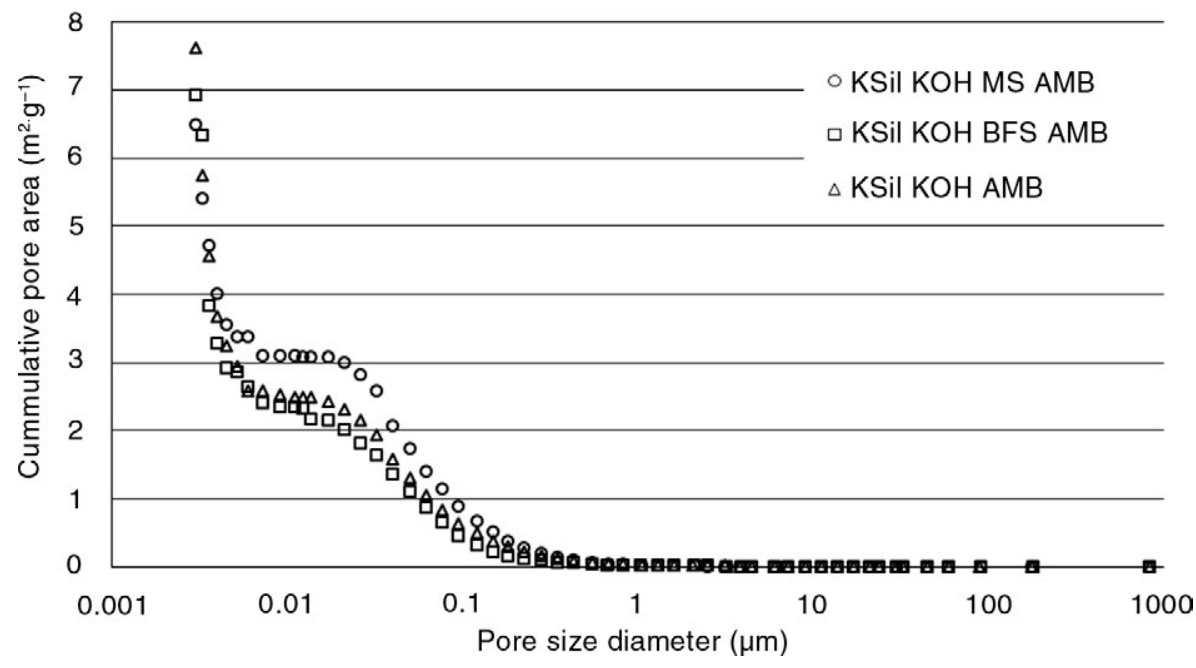

FIGURE $4 \mathrm{~b}$. Cumulative pore area $\left(\mathrm{m}^{2} \cdot \mathrm{g}^{-1}\right)$ vs Pore size diameter of KSilicate geopolymers.

strength (28). In the case of the K-Silicate geopolymer, the previous ratio is around 1.1 for a water/fly ash ratio of $0.34(28)$. The $\mathrm{K}_{2} \mathrm{O} / \mathrm{SiO}_{2}$ ratio in the current work is 1.45 for a water/fly ash ratio of 0.35 , so it is possible that an excess of alkali is being used. Some studies have concluded that geopolymer exposure to an excess of alkali resulted in the formation of certain species which has a deleterious effect on material properties (27).

Figures $5 \mathrm{a}$ and $5 \mathrm{~b}$ also show that the use of soluble silicate instead of hydroxide as activating solution increases the compressive strength. As can be seen in Figure 2a, Figure 2b and Table 4, hydroxidegeopolymers show a lesser degree of reaction and more porosity than silicate-geopolymers, which could explain the lower compressive strength values developed by hydroxide-geopolymers. Some authors have suggested that an activation process with soluble silicate produces more compact solids than those activated with hydroxide, possibly due to the fact that silicates improve the condensation process of the ionic species produced in the geopolymer reacting system (53).

BFS and MS slag are an additional source of $\mathrm{Si}$ and $\mathrm{Al}$ for the geopolymeric gel (apart from their extra supply of $\mathrm{Ca}$ ) and their effect on the compressive strength is apparent at early stages (at 7 days), especially for BFS geopolymers cured at $60{ }^{\circ} \mathrm{C}$. In these cases, the aforementioned coexistence of the sodium aluminium silicate hydrate gel and the calcium aluminium silicate hydrate gel could enhance the mechanical properties of geopolymer samples containing a moderate amount of blast furnace slag (44).

A different mechanical response to the addition of BFS or MS is observed. In spite of the similar $\mathrm{CaO}$ content of both slags, BFS-geopolymers exhibit higher compressive strengths than MS-geopolymers. As commented on before, the use of BFS produces 


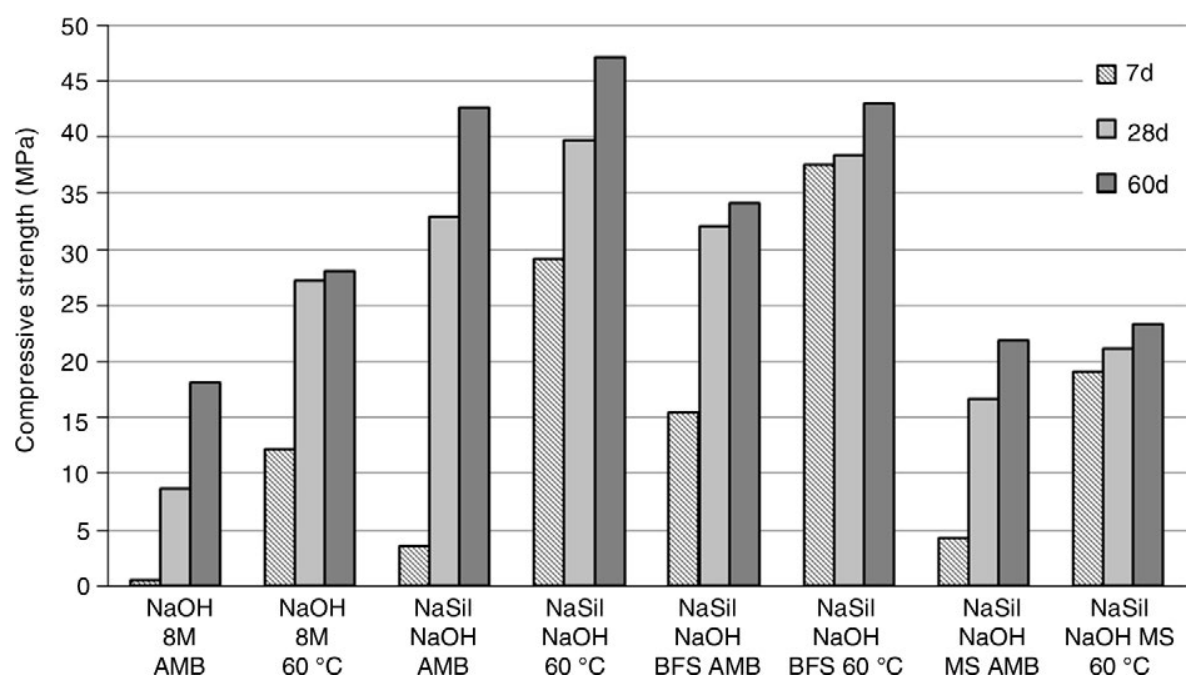

Figure 5a. Compressive strength of Na-geopolymers.

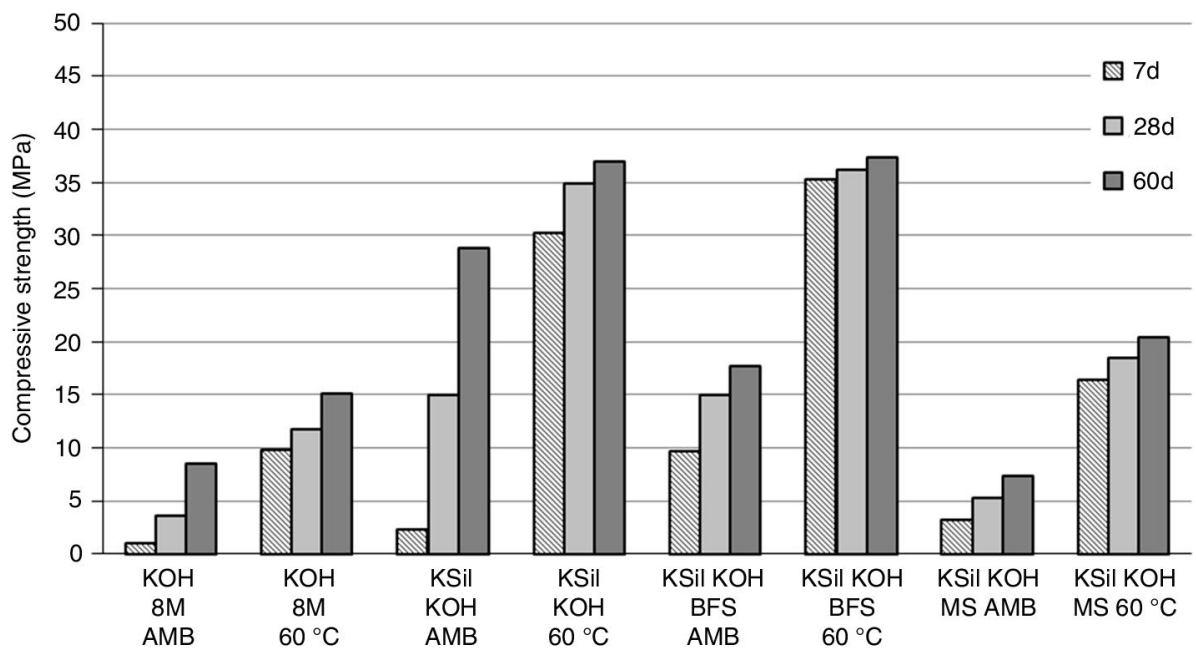

FIgure 5b. Compressive strength of K-geopolymers.

the least porous geopolymers with the highest degrees of reaction.

A high curing temperature improves the geopolymer's mechanical properties. In general, samples cured at $60^{\circ} \mathrm{C}$ show the highest compressive strength. Although the highest total porosity (Table 4) and the greatest total pore area (Figure 4a) are observed in thermally activated geopolymers, the pore size distribution is slightly shifted to the small pores (Figure $3 \mathrm{~b}$ and $3 \mathrm{c}$ ). This phenomenon can contribute to form a more uniform network with the subsequent strengthening of matrices, as commented on in the literature (46). In addition, compressive strength increases over time (7-60 days) but the growth rate varies. In general, K-geopolymers develop faster final compressive strength than Na-geopolymers (although their final compressive strength values are lower). Geopolymers cured at room temperature exhibit a slow hardening process, with low strength values at 7 days, although hardening is clearly obvious at 60 days. Furthermore, high compressive strengths at early stages of curing (7 days) are developed by most of the geopolymers cured at $60{ }^{\circ} \mathrm{C}$ and the values stabilise (or increase but at a slower rate) thereafter. Although it has been suggested that long curing times at high temperatures can produce failure in the structure of geopolymers caused by rapid dehydration and gel contraction (54), this effect has not been observed in the course of this research, where the compressive strength increases over time for any curing conditions.

\section{DISCUSSION}

Some relationships between degree of reaction, porosity and compressive strength are found in this work. The degree of reaction and compressive 
strength values have been analysed on the basis that, in principle, a high degree of reaction should lead to high compressive strength. The degree of reaction test was designed for conventional cementitious products, using $\mathrm{HCl}$, which mainly dissolves the calcium aluminosilicate hydrate phases. It has been assumed that, in geopolymeric products, $\mathrm{HCl}$ can also dissolve the geopolymeric gel (N-A-S-H or K-A-S-H) as well as C-A-S-H gels in geopolymers containing slags. Both gels can reasonably be considered responsible for the compressive strength developed by the geopolymers. As degree of reaction and compressive strength values are evaluated, some relationship seems to exist between both parameters: degree of reaction and compressive strength increase with the curing time, although not in the same proportion. A significant correlation seems to exist too, in the case of BFS containing geopolymers cured at $60{ }^{\circ} \mathrm{C}$ (although the same results are not found for MS geopolymers). However, in general, K-silicate geopolymers show higher degrees of reaction than Na-silicate geopolymers, although the compressive strength values are lower. This result is also mentioned by Wang et al. (52) who found a similar tendency between degree of reaction and compressive strength.

For a given curing temperature and activating alkali, porosity and compressive strength show an inverse proportion, as reported in the literature (21, $26,56)$. This relationship reflects compositional differences in the geopolymers, with a similar pattern regardless of the alkali and the curing temperature. Thus, for each series of data, geopolymers activated with hydroxide $(\mathrm{NaOH}$ or $\mathrm{KOH})$ solution present higher porosity and lower compressive strength than those activated with soluble silicate (NaSil or KSil), with or without slag. With the addition of BFS to the mixtures, the lowest porosity and the highest compressive strength are achieved. Systems with slags present the highest degree of reaction, which gives an idea of the percentage of solid gel formed during the geopolymerization reaction. This high degree of reaction depends on the chemical composition of the slag, but other physical properties must be taken into account: vitreous phase, reactivity and particle size distribution. It is worth noting that the addition of MS does not bring any benefit to the mixtures in terms of increasing compressive strength or reducing porosity, reflecting the totally different behaviour of the two slags, probably associated with their different particle size distribution.

Analysing the effect of curing temperature, the highest compressive strength and the highest porosity are obtained in all thermally activated geopolymers. The effect is more obvious in Na-geopolymers than in K-geopolymers. This direct relationship between porosity and compressive strength is not unusual and has been described by other authors (49). According to Kamseu et al. (57) compressive strength mainly depends on the pore size distribution, a variable more important than the total porosity, so the key to obtaining high mechanical properties geopolymers (compressive and flexural strength) is to control the pore size distribution.

The effect of alkali produces similar behaviour: for a given curing temperature, Na-geopolymers present slightly better mechanical properties than K-geopolymers, even though the porosities of the Na-geopolymers are higher. This gives the idea that the non-porous parts of materials activated with $\mathrm{Na}$-solutions is stronger than those activated with K-solutions. The direct relationship between compressive strength and porosity could reflect the changes in the pore size distribution described above, but could also be associated with the nature of the solid phases produced. However, it must be remembered that, apart from the porosity and pore size distribution, strength values depend on other parameters such as w/solid ratio, $\mathrm{M}_{2} \mathrm{O} / \mathrm{SiO}_{2}$ ratio, method of mixing and others, which can distort the comparison between $\mathrm{Na}$ and $\mathrm{K}$ geopolymers.

In summary, it is likely that the relationship between compressive strength and total porosity is masked by changes in the pore size distribution or other factors. To clarify this point, the relationship between mechanical properties and porosity of geopolymeric materials should be the aim of a more in-depth study.

\section{CONCLUSIONS}

The results of a study about the compressive strength, degree of reaction and porosity of different fly ash-based geopolymers are described in this paper. The main conclusions of this work can be summarized as follows:

- Geopolymers prepared using alkali hydroxide present a microstructure with a very low amount of geopolymeric gel, high porosities and poor mechanical properties. Conversely, geopolymers obtained after ash activation with alkali silicate show a more compact and closed structure, a high amount of geopolymeric gel, low porosities and high compressive strength.

- The use of sodium activators instead of potassium activators produces geopolymers with better mechanical properties.

- The effect of the slag (BFS or MS) addition on the mechanical properties of the geopolymer products is especially appreciable at early stages of the process (until 7 days) and after curing at $60{ }^{\circ} \mathrm{C}$. Moreover, geopolymers containing BFS exhibit higher resistances (and lower porosity values) than geopolymers with MS, possibly due to the coarser pore size distribution and lower reactivity of MS slag.

- An inverse correlation between compressive strength and total porosity has been observed in most of the geopolymers. However, thermally 
activated geopolymers (curing at $60{ }^{\circ} \mathrm{C}$ ) show the best mechanical properties and highest porosities (with a reduction in the geopolymer pore sizes). The same behaviour occurs in some Na-geopolymers, which are more porous and more resistant than similar K-geopolymers. Therefore, it can be concluded that the relationship between compressive strength and total porosity could, in some cases, be masked by changes in the pore size distribution or other properties related to the nature of the reaction products formed during the geopolymerization. Further studies are necessary to clarify the relationship between mechanical properties and porosity of geopolymeric pastes and to confirm the tendencies observed in this study.

- An attempt has been made to correlate the compressive strength and degree of reaction results. Although some relationships seem to exist, it is not entirely clear; therefore, new data which facilitate comparisons are required before deciding whether the degree of reaction is a suitable tool to study the compressive strength of the geopolymers.

\section{ACKNOWLEDGEMENTS}

The authors would like to acknowledge the financial support for this research by the Spanish Ministry of Science and Technology with European FEDER funds, under GEOPOL project (CTM2010-19917). The author would like to thank María del Carmen Jiménez del Haro (Material Science Institute (CSIC-US) for the contributions in the analysis SEM-EDX and Almudena Galiano Álvarez for the contributions in the analysis of porosity.

\section{REFERENCES}

1. WWCCPN. World-Wide Coal Combustion Products Network. http://www.wwccpn.org/ (2011) Last access: 2011.

2. Davidovits, J. (1991) Geopolymers: inorganic polymeric new materials. J. Therm. Anal. 37, 1633-1656. http://dx.doi. org/10.1007/BF01912193

3. Davidovits, J. (2005) The Poly (sialate) terminology: a very useful and simple model for the promotion and understanding of green-chemistry, Geopolymer chemistry and sustainable development, Proceedings of the World Congress Geopolymer, Perth, Australia (2005).

4. Van Jaarsveld, J.G.S.; Van Deventer, J.S.J.; Lukey, G.C. (2002) The effect of composition and temperature on the properties of fly ash- and kaolinite-based geopolymers. Chem. Eng. J. 89, 63-73. http://dx.doi.org/10.1016/ S1385-8947(02)00025-6

5. Xu, J.Z.; Zhou, Y.L.; Chang, Q.; Qu, H.Q. (2006) Study on the factors of affecting the immobilization of heavy metals in fly ash-based geopolymers. Mater. Lett. 60, 820-822 http://dx.doi.org/10.1016/j.matlet.2005.10.019

6. Izquierdo, M.; Querol, X.; Davidovits, J.; Antenucci, D.; Nugteren, H.; Fernández-Pereira, C. (2009) Coal fly ash-slag-based geopolymers: Microstructure and metal leaching. J. Hazar. Mater. 166 [1], 561-566. http://dx.doi. org/10.1016/j.jhazmat.2008.11.063
7. Izquierdo, M.; Querol, X.; Phillipart, C.; Antenucci, D.; Towler, M. (2010) The role of open and closed curing conditions on the leaching properties of fly ash-slag-based geopolymers. J. Hazar. Mater. 176 [1-3], 623-628. http:// dx.doi.org/10.1016/j.jhazmat.2009.11.075

8. Davidovits J. (2005) In Proceedings of the World Congress Geopolymer, Saint Quentin, France, 28 June-1 July pp. 9-15 (2005).

9. Sindhunata, Van Deventer, J.S.J.; Lukey, G.C.; Xu, H. (2006) Effect of curing temperature and silicate concentration on fly ash-based geopolimerization. Ind. Eng. Chem. Res. 45, 3559-3568. http://dx.doi.org/10.1021/ie051251p

10. Trochez, J.J.; Mejía de Gutiérrez, R.; Rivera, J.; Bernal, S.A. (2015) Synthesis of geopolymer from spent FCC: Effect of $\mathrm{SiO}_{2} / \mathrm{Al}_{2} \mathrm{O}_{3}$ and $\mathrm{Na}_{2} \mathrm{O} / \mathrm{SiO}_{2}$ molar ratios. Mater. Construcc. 65 [317]. http://dx.doi.org/10.3989/mc.2015.00814

11. Bernal, S.A.; Rodríguez, E.D.; Mejía de Gutiérrez, R.; Provis, J.L. (2015) Performance at high temperature of alkali-activated slag pastes produce with silica fume and rice husk based activators. Mater. Construcc. 65 [318] e049. http://dx.doi.org/10.3989/mc.2015.03114

12. Palomo, A.; Grutzeck, M.W.; Blanco, M.T. (1999) Alkali-activated fly ashes: A cement for the future. Cem. Concr. Res. 29 [8], 1323-1329. http://dx.doi.org/10.1016/ S0008-8846(98)00243-9

13. Provis, J.L.; Van Deventer, J.S.J. (2009) Geopolymers. Structures, processing, properties and industrial applications, Woodhead publishing Limited and CRC press LLC, (2009).

14. Lloyd, R.R.; Provis, J.L.; Smeaton, K.J.; Van Deventer, J.S.J. (2009) Spatial distribution of pores in fly ash-based inorganic polymer gels visualised by Wood's metal intrusion. Micropor. Mesopor. Mater. 126, 32-39. http://dx.doi. org/10.1016/j.micromeso.2009.05.016

15. Diamond, S. (2000) Mercury porosimetry. An inappropriate method for the measurement of pore size distributions in cement-based materials. Cem. Concr. Res. 30, 15171525. http://dx.doi.org/10.1016/S0008-8846(00)00370-7

16. Webb, P.A.; Orr, C. (1997) Analytical methods in fine particle technology. Micromeritics Instrument Corporation, Norcross, Ga USA (1997).

17. Zhang, Z.; Xiao, Y.; Huajun, Z. (2010) Potential application of geopolymers as protection coatings for marine concrete. II. Microstructure and anticorrosion mechanism. Appl. Clay. Science. 49 [1-2], 7-12 http://dx.doi. org/10.1016/j.clay.2010.04.024

18. Smilauer, V.; Hlavacek, P.; Skvara, F.; Sulc, R.; Kopecky, L.; Nemecek, J. (2011) Micromechanical multiscale model for alkali activation of fly ash and metakaolin. $J$. Mater. Sci. 46 [20], 6545-6555. http://dx.doi.org/10.1007/ s10853-011-5601-x

19. Kong, D.; Sanjayan, J.G.; Sagoe-Crentsil, K. (2007) Comparative performance of geopolymers made with metakaolin and fly ash after exposure to elevated temperatures. Cem. Concr. Res. 37 [12], 1583-1589. http://dx.doi. org/10.1016/j.cemconres.2007.08.021

20. Park, S-S.; Kang, H-Y. (2006) Strength and microscopic characteristics of alkali-activated fly ash-cement. J. Chem. Eng. 23 [3], 367-373. http://dx.doi.org/10.1007/BF02706736

21. Sindhunata; Provis, J.L.; Lukey, G.C.; Xu, H.; Van Deventer, J.S.J. (2008) Structural evolution of fly ash-based geopolymers in alkaline environments. Ind. Eng. Chem. Res. 47, 2991-2999. http://dx.doi.org/10.1021/ie0707671

22. Provis, J.L; Myers, R.J. White, C.E. Rose, V; Van Deventer, J.S.J. (2012) X-ray microtomography shows pore structure and tortuosity in alkali-activated binders. Cem. Concr. Res. 42, 855-864. http://dx.doi.org/10.1016/j. cemconres.2012.03.004

23. Li, Z.; Liu, S. (2007) Influence of Slag as Additive on Compressive Strength of Fly Ash-Based Geopolymer. J. Mater. Civil. Eng. 19 [6], 470-474. http://dx.doi. org/10.1061/(ASCE)0899-1561(2007)19:6(470)

24. Ma, Y.; Hu, J.; Ye, G. (2012) Effect of activating solution on mechanical strength, reaction rate, mineralogy, and microstructure of alkali-activated fly ash. J. Mater. Sci. 47 [11], 4568-4578. http://dx.doi.org/10.1007/s10853-012-6316-3 
25. Pan, Z.; Feng, K-N.; Gong, K.; Korayem, A.H.; Sanjayan, J.; Duan, W-H.; Collins, F. (2013) Damping and microstructure of fly ash-based geopolymers. J. Mater. Sci. 48, 3128-3137. http://dx.doi.org/10.1007/s10853-012-7090-y

26. Bhowmick, A.; Ghosh, S. (2012) Effect of synthesizing parameters on workability and compressive strength of Fly ash based geopolymer mortar. Int. J. Civil. Struct. Eng. 3 [1], 168-177.

27. Duxson, P.; Lukey, G.C.; Separovic, F.; Van Deventer, J.S.J. (2005) Effect of alkali cations on aluminum incorporation in geopolymeric gels. Ind. Eng. Chem. Res. 44 [4], 832-839. http://dx.doi.org/10.1021/ie0494216

28. Van Jaarsveld, J.G.S.; Van Deventer, J.S.J. (1999) The effect of the alkali metal activator on the properties of fly ash based geopolymers. Ind. Eng. Chem. Res. 38 [10], 3932-3941. http://dx.doi.org/10.1021/ie980804b

29. Phair, J.W.; Van Deventer, J.S.J. (2002) Effect of the silicate activator $\mathrm{pH}$ on the microstructural characteristics of waste-based geopolymers. Int. J. Miner. Process. 66, 121143. http://dx.doi.org/10.1016/S0301-7516(02)00013-3

30. Phair, J.W.; Van Deventer, J.S.J. (2001) Effect of silicate activator $\mathrm{pH}$ on the leaching and material characteristics of waste-based inorganic polymers. Miner. Eng. 14 [3], 289-304. http://dx.doi.org/10.1016/S0892-6875(01)00002-4

31. Kim, J.T.; Seo, D.S.; Kim, G.J.; Lee, J.K. (2010) Influence of alkaline-activator content on the compressive strength of aluminosilicate-based geopolymer. J. Korean. Ceram. Soc. 47 [3], 216-222. http://dx.doi.org/10.4191/ KCERS.2010.47.3.216

32. Abdul Rahim, R.H.; Rahmiati, T.; Azizli, K.A.; Man, Z.; Nuruddin, M.F.; Ismail, L. (2015) Comparison of using $\mathrm{NaOH}$ and $\mathrm{KOH}$ activated fly ash-based geopolymer on the mechanical properties. Mater. Sci. Forum. 803 (Geopolymer and Green Technology Materials), 179-184. http://dx.doi.org/10.4028/www.scientific.net/MSF.803.179

33. Nugteren, H.; Davidovits, J.; Antenucci, D.; Fernández Pereira, C.: Querol, X. (2005) Geopolymerization of fly ash. In Proceedings in Word of Coal Ash Conference, (2005).

34. ASTM D-3682-78. "Major and Minor Elements in Coal and Coke Ash by atomic Absorption.

35. Arjuan, P.; Silbee, M.R.; Roy, D.M. (1997) Quantitative determination of the crystalline and amorphous phases in low calcium fly ash. In: Proceedings of the 10th international congress of the chemistry of cement, Gothenburg, Sweeden, 3, 2-6 (1997). ISBN: 91630549739789163054976

36. Fernández-Jiménez, A.; Palomo, A.; Criado, M. (2005) Microstructure development of alkali activated Fly ash cement: a descriptive model. Cem. Concr. Res. 35, 1204 1209. http://dx.doi.org/10.1016/j.cemconres.2004.08.021

37. Fernández-Jiménez, A.; de la Torre, A.G.; Palomo, A.; López-Olmo, G.; Alonso, M.M.; Aranda, M.A.G. (2006) Quantitative determination of phases in the alkaline activation of fly ash. Part II: Degree of reaction. Fuel. 85, 1960-1969. http://dx.doi.org/10.1016/j.fuel.2006.04.006

38. Luna Galiano, Y.; Fernández Pereira, C.; Pérez, C.M.; Suarez, P. (2016) Influence of BFS content in the mechanical properties and acid attack resistance on fly ash based geopolymers. Key. Eng. Mat. 663, 50-61. (Processing ceramics from waste: A new raw material source for a global change) http://dx.doi.org/10.4028/www.scientific. net/KEM.663.50

39. ASTM C39/C39 M-05e2. Standard Test Method for Compressive Strength of Cylindrical Concrete Specimens.

40. Liabastre, A.A.; Orr. C. (1978) An evaluation of pore structure by mercury penetration. J. Colloid. Interf. Sci. 14 [1], 1-18. http://dx.doi.org/10.1016/0021-9797(78)90329-6

41. Ellison, A.H.; Kleman, R.B.; Schwartz, A.M.; Grubb, L.S.; Pretash. D.A. (1967) Contact angles of mercury on carious surfaces and the effect of temperature. J. Chem. Eng. Data. 12 [4], 607-609. http://dx.doi.org/10.1021/je60035a037
42. Fernández-Jiménez, A.; Palomo, A. (2003) Characterization of fly ashes. Potential reactivity as alkaline cements. Fuel. 82 [8], 2259-2265. http://dx.doi.org/10.1016/ S0016-2361(03)00194-7

43. Palomo, A.; Krivenko, P.; García-Lodeiro, I.; Kavalerova, E.; Maltseva, O.; Fernández-Jiménez, A. (2014) A review on alkaline activation: new analytical perspectives. Mater. Construcc. 64 [315], e022. http://dx.doi.org/10.3989/mc.2014.00314

44. Yip, C.K.; Luckey, C.G.; Provis, J.L.; Van Deventer, J.S.J. (2008) Effect of calcium silicate sources on geopolymerisation. Cem. Concr. Res. 38 [4], 554-564. http://dx.doi. org/10.1016/j.cemconres.2007.11.001

45. Yip, C.K.; Lukey, G.C.; Van Deventer, J.S.J. (2005) The coexistence of the geopolymeric gel and calcium silicate hydrated at the early stage of alkaline activation. Cem. Concr. Res. 35, 1688-1697. http://dx.doi.org/10.1016/j. cemconres.2004.10.042

46. Sindhunata. (2006) The mechanisms and kinetics of fly ash based geopolymerization. Ph.D. Thesis of University of Melbourne. Australia.

47. Kriven, W.M.; Bell, J.L. (2004) Effect of alkali choice on geopolymer properties. Ceram. Eng. Sci. Proc. 25 [3-4], 99-104. http://dx.doi.org/10.1002/9780470291191.ch16

48. Puligilla, S.; Mondal, P. (2013) Role of slag in microstructural development and hardening of fly ash-slag geopolymer. Cem. Concr. Res. 43, 70-80. http://dx.doi. org/10.1016/j.cemconres.2012.10.004

49. Kang, H-J.; Ryu, G-S.; Koh, G-T.; Kang, S-T.; Park, J-J. (2011) Relationship between microscopic structures and compressive strength of alkali-activated fly ash mortar. Key Eng. Mat. 452-453 (Advances in Fracture and Damage Mechanics IX), 737-740. http://dx.doi.org/10.4028/www. scientific.net/KEM.452-453.737

50. Nemecek, J.; Smilauer, V.; Kopecky, L.; Nemeckova, J. (2010) Nanoindentation of alkali-activated fly ash. Transp. Res. Record. 2141 (Nanotechnology in Cement and Concrete 2010, Volume 1) 36-40. http://dx.doi. org/10.3141/2141-07

51. Young, J.F.; Mindess, S.; Darwin, D. (2002) Concrete. Prentice Hall, Upper Saddle River (2002).

52. Fernández-Jiménez, A.; Palomo, A.; Criado, M. (2006) Alkali activated fly ash binders. A comparative study between sodium and potassium activators. Mater. Construcc. 56 [281], 51-65. http://dx.doi.org/10.3989/mc.2006.v56.i281.92

53. Kovalchuck, G.; Fernández-Jiménez, A.; Palomo, A. (2008) Alkali activated fly ash. Relationship between mechanical strength gains and initial ash chemistry. Mater. Construcc. 58 [291], 35-52. http://dx.doi.org/10.3989/mc.2008.v58. i291.101

54. Khale, D.: Chaudhary, R. (2007) Mechanism of geopolymerization and factors influencing its development: a review. J. Mater. Sci. 42 [3], 729-746. http://dx.doi. org/10.1007/s10853-006-0401-4

55. Wang, J.; Wu, X-L.; Wang, J-X.; Liu, C-Z.; Lai, Y-M. Hong, Z-K.; Zheng, J-P. (2012) Hydrothermal synthesis and characterization of alkali-activated slag-fly ashmetakaolin cementitious materials. Micropor. Mesopor Mater. 155, 186-191. http://dx.doi.org/10.1016/j. micromeso.2012.01.016

56. Muñiz-Villarreal, M.S.; Manzano-Ramírez, A.; SampieriBulbarela, S.; Gasca-Tirado, R.J.; Reyes-Araiza, J.L.; Rubio-Ávalos, J.C.; Pérez-Bueno, J.J.; Apatiga, L.M.; Zaldivar-Cadena, A.; Amigó-Borrás, V. (2011) The effect of temperature on the geopolymerization process of a metakaolin-based geopolymer. Mater. Lett. 65 [6], 995998. http://dx.doi.org/10.1016/j.matlet.2010.12.049

57. Kamseu, E.; Bignozzi, M.C.; Melo, U.C.; Leonelli, C. Sglavo, V.M. (2013) Design of inorganic polymer cements: Effects of matrix strengthening on microstructure. Constr. Build. Mater. 38, 1135-1145. http://dx.doi.org/10.1016/j. conbuildmat.2012.09.033 